\title{
Fostering Undergraduate Students' Reading Performance in English Discourse through Problem-Based Learning Model
}

\author{
Alek \\ Departement of English Education \\ UIN Syarif Hidayatullah Jakarta, Indonesia \\ Email:alek@uinjkt.ac.id
}

\begin{abstract}
:
Choosing and applying appropriate models or strategies in teaching and learning reading comprehension may lead to enhance the quality of both teacher and students' performance or achievement. Fostering students' reading performance is the primary endeavor to master other English skills. This investigation has done in five main stages which cover pre-test, planning, acting, observing, reflecting, and evaluation of the results. This recent study expects to reveal and describe the application of Problem-Based Learning (PBL) in fostering the students' reading English discourses. The instruments used in gathering the data were the observation sheets, questionnaire, and tests. There were 32 participants chosen to form the fourth-semester students which majoring in English education program of UIN Syarif Hidayatullah Jakarta. The data were analyzed qualitatively and quantitatively. The results show that the students' scores since the preaction test, first cycle up to the second cycle undergo increasing which tends to 'positive category' and ended with 'good level' (78 scores or high qualification category). It could be summarized that the application of PBL model towards EFL undergraduate students is effective in teaching and learning of English discourse reading comprehension.
\end{abstract}

Keywords: English reading discourses, problem-based learning, reading performance

\section{Introduction}

Good reading can only work well when students have an adequate concept of the discourse they read. The idea can be derived from information or problems of life that are being discussed on social media both electronic and printed reading discourses or texts. When reading an English text, students are faced with two core problems, namely the content of the reading and the words or sentences used to convey the intended meaning in the reading text (Singhal, 2001; Anderson \& Pearson, 1984). Students can only capture the messages in discourse when they understand 
the meaning of its words correctly. But through the discourses, which are being talked about, students can predict the meaning of words or sentences so that the messages in the discourse can also be understood (Tunmer \& Hoover, 2017).

Learning the reading discourse is not just starting to recognize letters, but reading and analysing the construction of sentences and diction used so that the message to be conveyed by the writer can be understood (Berkenkotter \& Huckin, 1993; Abasi, Akbari, Graves, 2006). That is, the readers' perception of the message they want to convey is the same or almost the same as the author's perception. For this purpose, students need to be introduced to various kinds of information that come from various sources through a variety of learning strategies.

Discourse coverage adopted based on the problem is certainly not only limited to the conditions and geographical environment of students but also the life experiences that they feel every day even on a national and international scale. These experiences can be in the form of activities with friends, experiences of watching TV shows, reading materials obtained from newspapers in the form of scientific information. According to Underwood \& Batt (1996) in teaching and learning reading comprehension of discourse or text needs various kinds or genres of the reading discourse or text and they can be obtained from various sources. For students to understand and capture the ideas contained in multiple discourses and sources in question, they need to be introduced to several types of learning experiences related to several kinds of life as well. In this context, it means that students need to learn how to read well so they can understand the concept well too. In Problem-Based Learning (PBL) or problem-based teaching for reading skill, reading discourse used as the teaching material contains popular problems being discussed both in printed and electronic mass media (Campos, 2017; Norman \& Schmidt, 1992; Major \& Palmer, 2001; Lin, 2018). Also, PBL can be a translation of trending topic or issue from Indonesian into English This is done when there is no English-language newspaper as the reference for teaching materials. This is in line with Lado (1988), arguing that the PBL model can use on the real problems or the made-up ones.

PBL also refers to the selection of teaching materials tailored to student needs. Student needs is oriented to the meaning that the instructional materials designed and taught must be related to the needs of students in everyday life. At least the theoretical knowledge gained in the classroom can immediately be felt when they return to society. This also means that the teaching materials provided must be closely related to the circumstances of the student's living environment.

As it is already mentioned in the previous that PBL or teaching-based on problems, basically is the presentation of teaching materials to students by adopting the news that is warmly discussed at that time or news that contains and contains certain issues. The teacher has a major role in adopting reading discourses based on problems so that what is at stake is not only his academic ability but also his ability to read the characteristics and will of students better known as professional abilities. Soedijarto (1989) stated that the professional ability required of a teacher is not only cognitive academic ability, but also the ability to organize teaching materials and adequate classroom arrangement. Reading activities in the sense of analyzing or studying a discourse are not only taught by language teachers, but by all teachers for all disciplines.

For language teachers, using language to teach language means that the language functions as a mental language. As for other disciplinary teachers, using language to explain the content of the disciplines they teach means functioning of language as a means of communication and 
disseminating information (Richards \& Rodgers, 2001). The notion that every teacher is a reading teacher (Underwood \& Batt, 1996) is how to teach students to read to understand the meaning of the discourse they are reading without considering the type of discipline being taught. That is, the ability of students to understand the concept of discourse or discourse that they read rests on their ability to connect the discourse that is being read with their experience or knowledge in the past so that they do not need the help of the teacher.

The ability of students to understand the message contained in a discourse without asking for help from the teacher is a parameter of the success of the teacher because reading activities involve self-skills to find out the message that the writer wants to convey. Although students are expected to be able to understand the concept of the discourse they read independently, it does not mean that the teacher does not play a role in the process of reading learning. The role, however, must be limited to a minimum margin because often the assistance provided more than student needs can have a negative impact, namely its dependence on teacher guidance every time they find even smooth reading discourse (Nuttall, 1996). To limit their role, teachers can incorporate reading discourse that fits the requirements of students and activities that are part of their hobbies.

Efforts to improve student's reading skills are to provide them with various types of discourses and integrate as far as possible the teaching of other skills even with other disciplines (Anderson \& Pearson, 1984). The efforts certainly require the maximum professional ability of teachers because the texts needed by the students are rarely available. This means that the teacher has the central role and responsibility in controlling the class activities along with the class running (Nuttall, 1996) then the discourses needed by students.

Some researchers have conducted some studies about problem-based learning, such as: motivation stimulus (Masek, 2015), soft skill and critical thinking (Zabit, 2010; Temel, 2014; Hamidah, 2015; Diansari, et al., 2017), designing course design (Genareo \& Lyons, 2015), and the teaching of English reading (Zulkifli, 2017; Lin, 2018).

\section{Literature Review}

\subsection{The Notion of Discourse}

The main prerequisites that should be considered by teachers in teaching reading discourses are (1) the discourse can provide information needed by students during learning in the classroom,

(2) reading discourse must be able to take students to the required information, and (3) exercises summarized in the reading discourse must be able well understood by students (Lapp, 1989).

It can be argued that the role of reading discourse adopted based on problems or problems engineered by teachers in the learning process is very urgent. It is because, on the one hand, he must be able to provide as much information as possible to students about what they want, while on the other hand, the essence of the reading discourse should not be contrary to the will of the curriculum. However, the role of the teacher as a designer or adapter for reading discourse is not small, because the smooth accountability of the learning process is on the teacher's shoulders, not on the reading discourse itself.

When giving the assignment, the teacher must consider the relationship between the content of the reading discourse and the class conditions. That is, the tasks assigned to students as far as possible can be solved without asking too many questions to the teacher, rather they can do it 
independently by reading the discourse carefully. Nuttall (1996) explains that guiding students to understand reading discourse does not mean that the teacher must describe all the contents of the discourse clearly and openly because it can reduce students' creativity. Instead, the teacher should familiarize them with the text and let them find for themselves the solutions to the problems contained in reading discourses.

Although good reading discourses compiled by expert writers or newspaper/magazine clippings made by teachers have been prepared in such a way, there are always gaps that must always be corrected. As argued by Nuttall (1996), there is no single reading discourse that can meet the needs of all students in one class. They expect to understand the method to grasp the content of any discourse they read.

\subsection{Some Constraints in Reading}

The challenges that merely occur in learning English as a foreign language for Indonesian students, such as low level of vocabulary mastery, lack of practicing, and having a low critical reading level. These challenges arise because of the learners' reading interest and low selfmotivation, self-efficacy, and self-confident. Anderson \& Pearson (1984) stated that the success of a student understanding and capturing ideas conveyed through discourse or foreign language texts are strongly influenced by his/her ability to read in the first language. So the main obstacle that arises when learning the discourse or text of English as a foreign language is hard to comprehend the discourse or the text itself.

This opinion, of course still needs to be polarized because, in many ways, students cannot understand the discourse of foreign languages due to their ignorance of the words and the construction of the sentence of the language. However, if the student has adequate knowledge of the topic written in the foreign language, they will be able to read well.

Students encountering difficulties in understanding and capturing foreign language texts may be due to several causes. The causes include: (a) students are not familiar with the signals contained in the text, (b) students do not have adequate initial knowledge about the content of the discourse, and (c) the concepts conveyed in the writing or discourse are very complicated (Nuttall, 1996). The signals used in a discourse covers the use of idiomatic words that require specific interpretations. Difficulties will also arise if the same words are used in different disciplines for different purposes.

\subsection{Problem-Based Learning Model}

Problem-Based Learning (PBL) model is a relatively new innovation in teaching and learning. This learning model needs and expects the students to have a competence to optimize their thinking ability autonomously or teamwork where students can select a concise learning model or strategy, skilled, and have a competence govern their learning process so that students may grow and enhance high-level thinking in problem-oriented conditions (Surindra, 2013; Hamidah, 2015; Yulita, 2013; Vijayalakshmi, 2016; Zabit, 2010).

In applying problem-Based Peraning (PBL), it allows for students to develop their skills for their future practices. It developes critical appraisal, literature retrieval, and encourages ongoing learning within a team environment. Next, the in using PBL model, it involves the learners working in small groups or team work. Each student takes on a role within the group that may 
be formal or informal and the role often alternates (Wood, 2003). Furthermore Wood stressed that the students may reflect themselves and construct their own learning.

Basically the constructs for teaching and learning using PBL are very different from the other kinds of teaching and learning models. In applying PBL, teacher or lecture frequently required more preparation time and materials to support the teamwork or small group learning (Hung, 2011). The using of PBL may enhance the students' motivation to achieve better achievement level than the students in traditional learning method because of their learning competencies, problem-solving, self-assessment techniques, and behavioral science (Vernon, 1995). It is because the students are good at maximizing the prior knowledge, and they learn in a context approaching their future context and elucidate more on the information presented which helps in better understanding and retention of knowledge.

\section{Research Methodology}

The present study used a classroom action research method. This research was design as a qualitative descriptive inquiry. This research inquiries its process was running in the natural setting, exploring the real experiences which are undergone by the students. The main intention of a qualitative study is to create a vast and rich description of the focus is being investigated (Magilvy, 2003).

This research was conducted in UIN Syarif Hidaytullah Jakarta. The main reason for choosing the cite was closely related to the characteristics and adequate of phenomena which supporting the recent study objectives (Creswell, 2013). The participants of the research were 32 fourth semester undergraduate students who were pursuing the Reading Comprehension Course in academic year 2018/2019. The present research was carried out in two cycles. Each cycle consisted of four meetings and was carried out for one month, respectively. Each cycle was carried out in line with the desired changes occurring in students' reading performance. The initial test was given before conducting the treatment in the classroom. The results of the test were considered as the initial scores.

The instrument used in collecting the qualitative data was the observation sheet. This observation sheet contained some aspects related to the students' activities along the learning process in the classroom. The other instrument used in collecting data of this research namely the questions about the application of the problem-based learning model during teaching and learning in the classroom. The quantitative data were obtained from questions about the English discourse reading and it was tested at the end of each cycle. Besides the data obtained through reading tests, data from the teacher's and students' activity during the application of PBL model in the classroom collected in each meeting.

Data analysis procedures of this study were adopted or followed (Miles \& Hubbermann, 1994) consists of three main stages data display, data reduction, and drawing the conclusion/verification. The first stage of data analysis was classifying the data based on its characteristics, the second, the data were input in the table, the third, calculated based on the genre of the data, the fourth stage, data were interpreted and reflected based on the theme occurred on each cycle, and the last stage, was conclusion drawing and verification. 


\section{Findings and Discussion}

After conducting classroom action research on efforts to increase the students' performance in reading English discourses. The students or participants of the current study is the fourthsemester undergraduate students of UIN Syarif Hidaytullah Jakarta in academic year 2018/2019. There are three main questions are presented and discussed in the following explanation.

4.1 To what extent were the students' English discourse performance before applying problembased learning model?

Regarding the data founded about the students' reading in English discourse, the researcher intended to answer the first question. Through answering this first question, it will be easy to fix the appropriate strategies or model which is applied in the teaching and learning process. The results of the initial test shows that the highest scores achieved by five students with the average scores are 57, it is in the qualification category 'Low,' five students or participants achieved average scores 55, 14 students obtained average scores 50, and the most students (20 students) obtained the average score 47. All the students' scores of reading performance in English discourses are at the qualification category 'Low." It can be inferred that none of those students' scores meet the success standard of minimum completeness $(=70)$. This result is similar to Cox et al., 2018) that the students, in the initial test, especially the reading materials are still strange for them, so that they cannot comprehend the author's intentionality of the reading discourses. This condition becomes reasonably accepted because of anyone who find any new discourses or texts are still difficult to comprehended well. In other words, when one is not familiar with the discourses or texts, it usually must feel difficult. Another research result which is still closely related to this condition as (Chiang, 2018) founded that the problems of the students in comprehending the discourses or texts may be caused by some aspects such as vocabulary size, prediction ability, and receptive vocabulary.

4.2 How did the PBL model help the teacher to teach reading comprehension more effectively to the undergraduate students of the English department at UIN Syarif Hidaytullah Jakarta?

After data were collected, both the results of the test at the end of the first cycle and the students' activity along with the teaching and learning activities in the classroom. The process of teaching and activities in EFL classroom consists of four major stages, planning the action, acting or implementing the action, observation, and reflection or evaluation. In this subtitle is presented two main parts of the research results (1) the results from the first cycle and (2) the results of the second cycle. The complete presentation of the research results is presented consecutively below.

\subsubsection{Cycle 1}

As the intention of the second question of the recent study, the researcher expects to find out the students' development of their performance in reading English discourse. The data and finding of the first cycle was 54 or it was in the qualification category low level, from the second meeting was achieved the average of the researcher's performance during teaching reading comprehension was 54 or it was in the qualification performance was 57 still in the 'low' level, meanwhile in the further meeting (meeting three) has increased to the middle level qualification category with average point at 63 . Surprisingly increased at the final meeting of the first cycle was achieved averaged score 68 , it still the same level category as in the meeting three. It still did 
not meet the standard or success indicator, which was determined at the 'good level' or the average score at $70-80$ ).

In line with the finding above, Feiman-Nemser (2001) express that the teacher should produce more powerful learning opportunity for their students, through doing that the students may elevate their motivation and learning professionally. In line with Feiman-Nemser, Warlick (2004) also mentioned that the role of instructor or teacher in developing students' competence such as engaging and giving clear information and guidance when teaching and learning process. Furthermore, the researcher's performance during teaching reading comprehension using the PBL model was 54 score, and it is categorized low level.

Meanwhile, the teacher recorded the students' activities. It shows that the success indicators for the students activity performance when the teacher is applying the PBL in the classroom in meeting one is still in the qualification category 'low level,' from meeting two up to meeting four are still at the qualification category 'middle level,' but in the meeting three, the number of students' activity is more than in the meeting one and meeting two. Meanwhile, in meeting three and meeting four, more students do the activity more often than in the two sessions before.

After conducting the teaching and learning using the PBL model, the researcher conducted the post-test in cycle 1. The average scores of the students' performance in reading English discourses model shows that the students' performance in reading English discourses is in 60.12 average scores and it is in the qualification category 'middle.' This result is related to the Jose \& Raja (2011) state that the process of reading comprehension of English discourses required high concentration when reading lines by lines or reading between the lines. Having the wellprepared in facing the test, the student may have big opportunity to obtain a good result. Regarding the post-test result of the first cycle, Jose \& Raja stress that teacher's awareness for drilling the students many more times in facing any tests. The teacher should teach the students some basic competences, such as assumptions, inferences, and conclusions, and judges the accuracy based on their prior knowledge and experiences.

\subsubsection{Cycle 2}

Comparing to the result of the researcher's performance in the first cycle, the researcher's performance in the second cycle has undergone much more development than that has happened in the previous cycle (cycle one). The results of the researcher's activity performance average scores in the second cycle was 69.34 , or it underwent the development of average scores compared to the first cycle before, and it was in the qualification category 'middle level,' from the second meeting up to four meetings were achieved the average scores, meeting two was 75 , meeting three was 78.3 score, and meeting four was 82.12 scores. So the last three sessions have undergone the development of the students' reading performance or achievement in English discourses. It can be inferred that the researcher's activity performance average score in teaching English reading comprehension course has met the standard of success. So the total average scores of the researcher's performance in teaching reading comprehension using the PBL model is at the 'good level' or the average scores $=78.19$.

The next data is going to present the students' activities based on the result of observation during the teacher applied the PBL model in the teaching and learning process in the classroom. The results of students' activity shows that the success indicators for the students' activity performance when the teacher was applying the PBL in the classroom from meeting one up to 
the meeting three, the students' activity performance average score was in the qualification category 'high level (79),' meanwhile in the meeting four, the students' activity performance average score at the qualification category 'the highest level (86).' From those meeting, the total students' activity performance average score was 77.75. After conducting the teaching and learning using the PBL model, the researcher did the post-reading test at the end of the second cycle

The average scores of the students' performance in reading English discourse shows the comparison of all average scores achieved from the pre-action test, first cycle, and the third cycle.

Table : The Comparison of the Students' Reading Test Results in Pre-Action, Cycle 1 \& Cycle 2

\begin{tabular}{lcc}
\hline Test Types & Average Scores of Test esults & Qualification Category \\
\hline Pre-Action Test & 52.25 & Low \\
Cycle 1 & 60.12 & Middle \\
Cycle 2 & 78 & High \\
\hline
\end{tabular}

Based on the results as depicted in Table above, the students' scores underwent the development since the pre-action test up to cycle 2 . The difference from the pre-action test/initial test to the post-test in the first cycle was 7.87 points. Meanwhile, the different test results of the students' performance in reading comprehension of English discourses between the first cycle and the second cycle was 17.88 points. Referring to these results, the researcher concluded that the students had presented their positive and good responses toward the application of the ProblemBased Learning (PBL) Model during the teaching and learning of English discourses reading comprehension. The test results show that the scores underwent fostering gradually since the pre-action test, the first cycle up to the second or last cycle. These are proved by the average scores at the second cycle which is 78 or high qualification category as illustrated above. Thus it could be stated that the students'performance or achievement in reading English discourses had achieved and exceeded the standard of the success proposed in this study 75 or 3.00 . The results as found in recent research is in supported by research result conducted by Lin (2018) stated that the applying PBL model in reading comprehension course was significantly affected. Another result comes from Temel (2014), in his research finding that reports PBL increasing pre-service teachers perceptions of problem-solving ability in teamwork skills, skill in exploring the information within the reading text, and having discipline-based problems.

4.3 What were the students' responses to the application of PBL model in teaching English reading comprehension class?

The data were from the students regarding their real experiences when following the lecture in the classroom. The students were asked to give responses to the application of PBL model in teaching and learning of the reading discourses or texts. The questionnaire/questions used to understand the students' agreement, acceptance, and easiness level of applying PBL model based on their experiences. The questionnaire/questions provided four choices in each item, they are strongly agreed, agree, somewhat agree, and disagree. It shows the students' responses to the application of PBL Model in Teaching and learning reading comprehension at the undergraduate students of the Departement of English Education. There are three categories of the students' responses related to the application of PBL; the first is the strongly agree in $(\mathrm{n}=$ $18 / 56.35 \%)$, the second is agree in $(n=9 / 28.12 \%)$, somewhat agree in $(n=n 5 / 15.62 \%)$. A 
significant different between strongly agree $(\mathrm{n}=18 / 56.35 \%)$, and somewhat agree $(\mathrm{n}=\mathrm{n}$ $5 / 15.62 \%)$, while between strongly agree in $(n=18 / 56.35 \%)$ and agree in $(n=9 / 28.12 \%)$ is a half difference. Based on data, it can be said that there is slightly different between the total number of the students who are in 'strongly agree' than the total students in both 'agree' and 'somewhat agree.' In other words, the application of PBL at the undergraduate students of the Departement of English Education of the State Islamic University is at the middle level agree.

Furthermore, the data founded about the students' responses to the application of PBL Model in Teaching and learning reading comprehension at the undergraduate students of the Departement of English Education underwent the increasing than as happened in the first cycle. The data of the students' responses in the second cycle shows of three groups of the students' responses related to the application of PBL model; the first is strongly agree in $(n=24 / 75 \%)$, the second is 'agree' in $(n=6 / 18.75 \%)$, and 'somewhat agree' in $(n=2 / 6.25 \%)$, while the level of disagree is void (0). Compared to cycle one, strongly agree is the highest students number ( $\mathrm{n}=$ $24 / 75 \%)$ than from both 'agree' and 'somewhat agree' which total $(n=8 / 25 \%)$. Meanwhile, none of the student who chooses to disagree. Based on data, it summarized that most undergraduate students of the Departement of English Education of the State Islamic University wish to learn or to be taught using PBL model in learning the reading comprehension course.

Related to the finding above, Diansari et al. (2017) proved that applying the Problem-Based Learning (PBL) model may motivate and enhance the students' creativity, especially in exploring the information by themselves. Furthermore, Diansari stressed that learning through applying the PBL can be able to optimize the students thinking performance and can explore their selfcompetence and even could establish their team-work (create grouped-learning). Another research conducted by Zulkifli (2017) reported in his study that the use of Problem Based (PBL) model in teaching reading comprehension for the eighth-grade students to the students is effective and has been accepted positively when teaching and learning process in the classroom. Regarding to both studies were conducted by Diansari et al. (2017) and Zulkifli (2017) above, confirm that the Problem-Based Learning (PBL) model could help the learners of English as a foreign language, especially in learning reading comprehension and it is more surprisingly this successfulness is not only at middle-level students but on secondary school-level learners as well. The other important aspect may contribute to the successfulness of applying the PBL model in teaching reading comprehension, Masek (2015) states that in conducting teaching and learning process both teacher and learners having fundamental spirit, self-motivation, braveness, and having strong intrinsic motivation in facing any challenges. Having internal motivation, the students will learn independently his/her tasks or activity with high self-consciousness.

\section{Conclusion}

This recent study aimed to reveal the students' reading performance in English discourse through the problem-based learning model. To achieve this objective the researcher has conducted pre-action/initial test, did the research in the classroom, and post-action tests, both in the first and the second cycles. Based on the students'and teacher's activities during the teaching and learning in the classroom from the first meeting up to the last meeting in each cycle. In all the process have run-well which indicated by the students' positive and good responses toward the application of the Problem-Based Learning (PBL) Model. Furthermore, looking at the test results show that the students' scores since pre-action test, first cycle up to the second or last cycle (cycle 2) developed gradually which tends to 'positive category' and ended with 'good level' 
(78 or high qualification category). Based on the results elucidated above, it could be concluded that the applichangcation of PBL model towards EFL students in teaching and learning of English reading comprehension, especially the fourth-semester undergraduate students of the Department of English Education of the State Islamic University is success.

\section{References}

Abasi, A. R., Akbari, N., \& Graves, B. (2006). Discourse Appropriation, Construction of Identities, and the Complex Issue of Plagiarism: ESL students writing in graduate school. Journal of Second Language Writing, 15(2), 102-117.

Anderson, R. C., \& Pearson, P. D. (1984). A Schema-theoretic View of basic Processes in Reading Comprehension. Handbook of Reading Research, 1, 255-291.

Berkenkotter, C., \& Huckin, T. N. (1993). Rethinking genre from a sociocognitive perspective. Written communication, 10(4), 475-509.

Campos, D. (2017). Problem-Based Learning: An Experiential Strategy for English Language Teacher Education in Chile. Profile Issues in Teachers Professional Development, 19(1), 2940.

Cox, Troy L., Jennifer Bown, Teresa R. Bell. (2018). In Advanced L2 Reading Proficiency Assessments, Should the Question Language Be in the L1 or the L2?: Does It Make a Difference? https://link.springer.com/chapter/10.1007/978-3-030-01006-5_7.

Creswell, J.W. (2013). Qualitative Inquiry \& Research Design: Choosing among Five Approaches (3rd ed.). Thousand Oaks, CA:SAGE.

Diansari, Agustin Ayu Rizki., Suratman,Bambang \& Soejoto, Ady. (2017), The Effect of Problem-Based Learning Model, Learning Audio Visual Media and Internship on Student's Soft Skill, https://www.researchgate.net/publication/325122778_The_Effect_of_ProblemBased_Learning_Model_Learning_Audio_Visual_Media_and_Internship_on_Student's_So $\mathrm{ft} \_$Skill

Feiman-Nemser, S. (2001). From preparation to practice: Designing a continuum to strengthen and sustain teaching. Teachers College Record, 103(6), 1013-55

Genareo, Vincent R. \& Lyons, Renee. (2015). Problem-based learning: six steps to design, implement, and assess. Retrieved from https://www.facultyfocus.com/articles/coursedesign-ideas/problem-based-learning-six-steps-to-design-implement-and-assess/November 30th, 2015

Hamidah, S. (2015). Integrated Problem based Learning for Improvement Soft Skill and High Order Thingking of Vocational Students. International Conference on Innovation in Engineering and Vocational Education, 3(4).

Hung, Woei. (2011). Theory to Reality: A few Issues in Implementing Problem-based Learning. Educational Technology Research and Development. 59 (4): 529-552.

Jose, G. Rexlin \& Raja, B. William Dharma. (2011). Teachers' role in fostering reading skill: effective and successful reading. Journal on English Language Teaching, 1(4), 2011.

Lapp, Diane. (1989). Teaching Literacy in first Grade: Handbook of Research on Teaching Literacy through the Communicative and Visual Arts. New York: Teachers College Press

Lado, Robert. (1988). Teaching English across Culture: An Introduction for Teachers of English to Speakers of Other Languages. Singapore: Kim Hup Lee Printing Co. Pte. Ltd. 
Lin, L. F. (2018). Integrating the problem-based learning approach into a web-based English reading course. Journal of Educational Computing Research, 56(1), 105-133.

Magilvy, J.K., \& Thomas, E.E. (2009). A First Qualitative Project: Qualitative Descriptive Design for Novice Researchers. Journal for specialists in pediatric nursing : JSPN, 14(4), 298-300

Masek, Alias. (2015). Problem based learning instruction approaches for students' intrinsic motivation stimulus. International Journal of Vocational Education and Training Research, 1(3): 42-48.

Major, C., \& Palmer, B (2001). Assesing the Effectiveness of Problem Based Learning in Higher Educatin: Lesson from the Literature. Academic Exchange Quarterly 5(4), 4-11.

Miles, MB \& Hubberman, AM. (1994). Qualitative Data Analysis. USA: SAGE Publication.

Norman, GR \& Schmidt, HG (1992).The Psychological Basis Of Problem-Based Learning: A Review Of The Evidence. Academic Medicine, 67 (9).

Nuttall, Christine. (1996). Teaching Reading Skills in a Foreign Language. USA: Heinemann

Richards, Jack C. \& Rodgers, Theodore S. (2001). Approaches and Methods in Language Teaching. Melbourne: Cambridge University Press.

Singhal, M. (2001). Reading Proficiency, Reading Strategies, Metacognitive Awareness, and L2 Readers. The Reading Matrix, 1(1). 2001

Tunmer, W. E., \& Hoover, W. A. (2017). Cognitive and Linguistic Factors in Learning to Read. in Reading Acquisition. Routledge.

Soedijarto (1989) Pendidikan sebagai Sarana Reformasi Mental dalam Upaya Pembangunan Bangsa. Jakarta: Balai Pustaka.

Surindra, B. (2013). Penerapan Model Pembelajaran Berbasis Masalah Dengan Media Power Point Dalam Peningkatan Hasil Belajar Jurnal Khusus Perusahaan Dagang Kelas AK 2 di SMK Pemuda Krian Sidoarjo. Jurnal Pendidikan, 2 (1), 2013

Temel, Senar. (2014). The effects of problem based learning on preservice teachers' critical thinking dispositions and perceptions of problem solving ability. South African Journal of Education, 5(3): 155-165.

Underwood, Geoffrey \& Batt, Vivienne (1996). Reading and Understanding. USA: Blackwell Publisher.

Vernon, D. T. (1995). Attitudes and opinions of faculty tutors about problem-based learning. Academic Medicine. 70 (3): 216-223.

Vijayalakshmi. (2016). Soft skills-the need of the hour for professional competence: a review on interpersonal skills and intrapersonal skills theories. International Journal of Applied Engineering Research, 11(4), 2859-264.

Warlick, David F. (2004). Redefining Literacy for the 21st Century. USA: Linworth Publishing Inc.

Wood, D. F. (2003). "ABC of learning and teaching in medicine: Problem based learning". BMJ. 326 (7384): 328-330.

Yulita, M. (2013). Pengaruh metode problem based learning terhadap proses pembelajaran dan peningkatan softskill mahasiswa akuntansi. Jurnal Pendidikan, 4(1).

Zabit, M. N. (2010). Problem-based learning on students ${ }^{\text {se }}$ critical thinking skills in teaching business education in Malaysia: A literature view. American Journal of Business Education, $3(6)$.

Zulkifli. (2017). The Use of Problem Based (PBL) Learning in Teaching Reading. Voices of English Language Education Society (VELES), 1(1); April 2017 